\title{
The Effect of Lycopene on Cancer Cell Apoptosis by Caspase-9 Concentration Measurement in Indonesian Human Prostate Cancer Cell Culture
}

\author{
Tjahjodjati Tjahjodjati $^{1 *}$, Suwandi Sugandi ${ }^{1}$, Rainy Umbas ${ }^{2}$, Mieke Satari ${ }^{3}$ \\ ${ }^{1}$ Department of Urology, Faculty of Medicine, Padjadjaran University, Dr. Hasan Sadikin General Hospital, Sumedang, \\ Indonesia; ${ }^{2}$ Department of Urology, Faculty of Medicine, University of Indonesia, Cipto Mangunkusumo Hospital, Jakarta, \\ Indonesia; ${ }^{3}$ Doctoral Program, Faculty of Medicine, Padjadjaran University, Sumedang, Indonesia
}

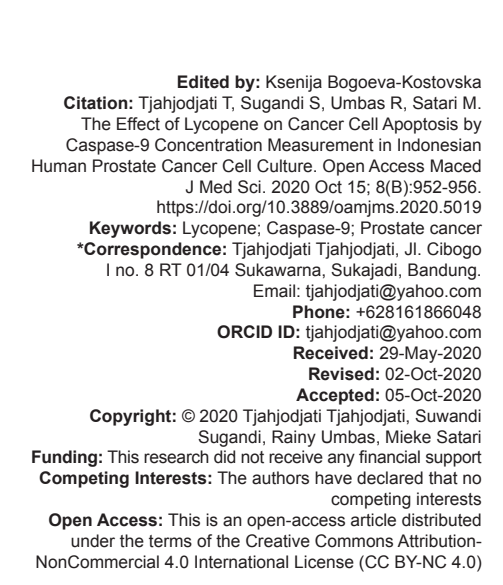

Abstract

BACKGROUND: Lycopene is an antioxidant that mostly found in daily ingredients such as tomatoes. Several studies have shown the lycopene potential in preventing prostate cancer. Nevertheless, the clinical use of lycopene as adjunctive therapy for prostate cancer is still under debate.

AIM: The objective of the study was to determine the effect of lycopene on human prostate cancer cell culture growth by measuring caspase- 9 concentration as a marker of the intrinsic pathway of apoptosis in cells.

METHODS: This study was conducted on Indonesian prostate cancer cell culture from a patient with Gleason score 6 , divided into 5 subgroups: 2 control groups and 3 treatment groups that were given $1 \mu \mathrm{M}, 2 \mu \mathrm{M}$, and $4 \mu \mathrm{M}$ of lycopene. Measurement of caspase-9 level was performed using enhanced chemiluminescence at 24,28 , and $72 \mathrm{~h}$ after lycopene addition in treatment groups. A comparative analysis was performed by two-way ANOVA.

RESULTS: The result showed that there was a significant difference of mean caspase- 9 levels in the provision of various concentrations of lycopene and time of observation $(p<0.05)$. Increased of mean caspase- 9 levels started at $2 \mu \mathrm{M}$ dose of lycopene at $48 \mathrm{~h}$ and $4 \mu \mathrm{M}$ at $24 \mathrm{~h}(\mathrm{p}<0.05)$ and continue to rise at $72 \mathrm{~h}$, but caspase-9 was not detected at $1 \mu \mathrm{M}$ dose in every observation.

CONCLUSION: There was a significant difference of mean caspase-9 levels in the provision of various concentrations of lycopene and time of observation.

\section{Introduction}

Prostate cancer is the most common malignant disease of urology and also the most common noncutaneous malignancy in males. Globally, there were an estimated 782,600 new cases and 254,000 cancer deaths in 2007 [1]. The incidence of prostate cancer in various Asian countries increases with a range of $5-118 \%$ [2]. Until present, the exact cause of prostate cancer is not known yet. However, some reports suggest that there are several risk factors for prostate cancer such as environment and genetic [3].

Another factor that plays an important role in the occurrence of prostate cancer is nutrition. Tambunan and Umbas reported that some nutrients had protective effects against the risk of prostate cancer, including tomato/lycopene, soy, cruciferous vegetables, green tea, and other polyphenolic compounds [4]. Several epidemiologic studies that observe groups of people with a low incidence of malignancy are conducted to determine and reduce the risk of prostate cancer. Vecchia; Rao and Agarwal; and Basu and Imrhan conducted several case-control studies in the period of 1983-1992, found that in a Mediterranean population, who consumed many fruits and vegetables, including tomatoes, had a low incidence of malignancy [5], [6], [7]. A case-control study in Minnesota found that people who consumed tomatoes more than 14 times/month had a lower risk of prostate cancer than those who ate tomatoes $<3$ times/ month [8]. Many studies concluded a protective effects of lycopene on prostate cancer [9], [8], [10], [11].

Siler et al. reported that lycopene increases the rate of necrosis in mice prostate cells. This corresponds to the decrease in local androgen regulatory signals and the expression of caspase-9 and interleukin 6 [12]. Tang et al. found that lycopene inhibited the growth of prostate cancer cells in vitro in male mice [13]. Research on humans reported by Obermuller-Jevic et al. found that lycopene inhibited the growth of normal human prostate epithelial cells in vitro (Prec-clone 6448) [14].

Lycopene became potential as a supplementary treatment for prostate cancer due to its known mechanism, typically inhibit the progressivity of cancer, that is, cell growth [15], [16]. Lycopene was expected to delay its progression and improve the survival rate of patients [7]. Although tomatoes are widely consumed 
in Indonesia, there is no study regarding the effect of lycopene on prostate cancer in Indonesia. Hence, this study was conducted to determine the effect of lycopene on the level of caspase- 9 in Indonesian human prostate cancer cell.

\section{Materials and Methods}

\section{Materials}

Materials of this study were tissues of prostate cancer obtained from prostate cancer patients admitted to DR. Hasan Sadikin General Hospital Bandung, who had undergone radical prostatectomy with the pathological result of Gleason score 6. Caspase- 9 was measured using caspase- 9 assay kit (Colorimetric) ab65608 Abcam.

\section{Methods}

The tissue obtained from radical prostatectomy then underwent a frozen section examination conducted by a pathologist to determine the location of prostate cancer. About $1 \mathrm{~g}$ of specimen was taken from area where shown positive for prostate cancer. The specimen with Gleason score of 6 was obtained after examined by a pathologist. It was placed in transport media contained a solution of Dulbecco's modification of Eagle's minimal essential medium (DMEM/F12) and antibiotic (penicillin100 U/mL, streptomycin $100 \mu \mathrm{g} / \mathrm{mL}$, amphotericin B $250 \mu \mathrm{g} / \mathrm{mL}$, and gentamicin $50 \mu \mathrm{g} / \mathrm{mL}$ ) [17]. It was transported at a temperature of $4^{\circ} \mathrm{C}$ to Biotechnology (Biotec) Laboratory in Rajawali Hospital, then underwent culture and subculture to attain enough number of cells to be utilized. The steps of the procedure were as follows:

1. Primary culture of prostate cancer (enzymatic disaggregation)

Primary prostate cancer cultures were prepared by incubation using $0.3 \%$ type 1 collagenase at $37^{\circ} \mathrm{C}$. The results of the incubation were carried out by centrifugation at a speed of $2000 \mathrm{rpm}$ to form pellets from prostate cancer. The incubation was carried out for 5-7 days with a temperature of $37^{\circ} \mathrm{C}$ and $5 \% \mathrm{CO}_{2}$ levels. After 5-7 days, the cells adhering to the bottom of the plate were observed under a microscope.

2. Cell multiplication method (subculture)

Cell propagation is done by dissociating cells from previous cultures. Cells were incubated after adding the Trypsin EDTA (Biosera) solution for 2-5 min. Cells were suspended and centrifuged at $2000 \mathrm{rpm}$ for $5 \mathrm{~min}$. The supernatant was removed; the pellets were implanted in 2-6 growth medium.

\section{Histopathology examination \\ 4. Prostate cancer cell treated with lycopene}

The method of treating prostate cancer cell with lycopene was as below:

- $\quad$ Lycopene was dissolved in dimercaptosuccinic acid into $1 \mu \mathrm{M}, 2 \mu \mathrm{M}$, and $4 \mu \mathrm{M}$ concentrates

Prostate cancer tissue culture was divided into 5 groups with 2 control groups (Group A and $B$ ) and 3 treated groups (Groups C, D, and $\mathrm{E}$ ). Each group consisted of 500,000 cells (Figure 1).

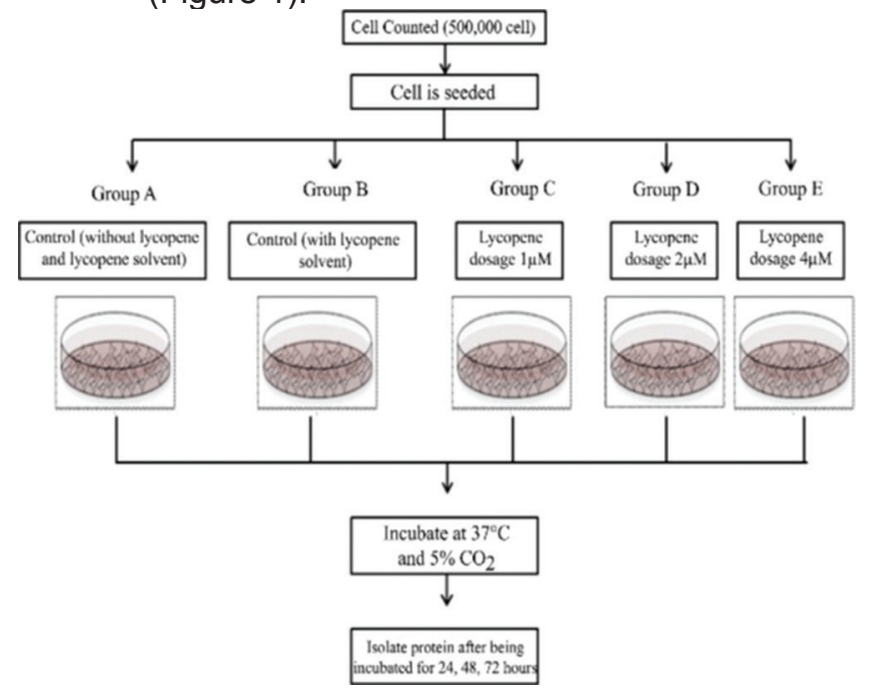

Figure 1: Group of prostate cancer cell subculture

- Group A was neither treated with lycopene nor lycopene solvent

- $\quad$ Group B was not treated with lycopene but was given lycopene solvent

- $\quad$ Group C was treated with $1 \mu \mathrm{M}$ lycopene [18]

- $\quad$ Group D was treated with $2 \mu \mathrm{M}$ lycopene [19]

Group E was treated with $4 \mu \mathrm{M}$ lycopene.

All groups were incubated at $37^{\circ} \mathrm{C}$ and in $5 \%$ CO2 for $24 \mathrm{~h}, 48 \mathrm{~h}$, and $72 \mathrm{~h}$.

5 . Isolation of total protein from prostate cancer cell

6. Measurement of caspase-9 protein concentration by ELISA

Analysis was performed using a two-way analysis of variance (ANOVA) with the $F$ test at a confidence interval of $95 \%$ using SPSS version 21.0 for Windows.

\section{Results}

The average increase in caspase-9 level compared to control (Group A and B) became visible after the administration of $2 \mu \mathrm{M}$ lycopene (Group D) which occurs at the 48-h observation time. The level of caspase-9 increasing from $0.250 \mathrm{ng} / \mathrm{ML}$ to $0.635 \mathrm{ng} / \mathrm{mL}$ at the $72-h$ mark. Furthermore, the administration of 
$4 \mu \mathrm{M}$ lycopene (group E) caused an increase in mean caspase-9 level compared to control after $24 \mathrm{~h}$ as much as $0.340 \mathrm{ng} / \mathrm{mL}$, and continuously increased after 48 - and $72-\mathrm{h}$ observation time $(0.585 \mathrm{ng} / \mathrm{mL}$ and $0.605 \mathrm{ng} / \mathrm{mL}$, respectively) (Table 1 and Figure 1).

Table 1: Mean caspase-9 levels based on lycopene concentration and observation time

\begin{tabular}{|c|c|c|c|c|}
\hline $\begin{array}{l}\text { Treatment } \\
\text { group }\end{array}$ & $\begin{array}{l}\text { Observation } \\
\text { time }\end{array}$ & $\begin{array}{l}\text { Average (SD) } \\
\text { (ng/mL) }\end{array}$ & Range & $p$-value ${ }^{*}$ \\
\hline \multirow[t]{4}{*}{ 1. Group A } & $24 \mathrm{H}$ & 0 & 0 & \multirow{20}{*}{$\begin{array}{l}\text { F value (between } \\
\text { treatment groups) }= \\
4694,86 ; p=0.001 \\
(p<0.05)\end{array}$} \\
\hline & $48 \mathrm{H}$ & 0 & 0 & \\
\hline & $72 \mathrm{H}$ & 0 & 0 & \\
\hline & Combined & 0 & 0 & \\
\hline \multirow[t]{4}{*}{ 2. Group B } & $24 \mathrm{H}$ & 0 & 0 & \\
\hline & $48 \mathrm{H}$ & 0 & 0 & \\
\hline & $72 \mathrm{H}$ & 0 & 0 & \\
\hline & Combined & 0 & 0 & \\
\hline \multirow[t]{4}{*}{ 3. Group C } & $24 \mathrm{H}$ & 0 & 0 & \\
\hline & $48 \mathrm{H}$ & 0 & 0 & \\
\hline & $72 \mathrm{H}$ & 0 & 0 & \\
\hline & Combined & 0 & 0 & \\
\hline \multirow[t]{4}{*}{ 4. Group D } & $24 \mathrm{H}$ & 0 & 0 & \\
\hline & $48 \mathrm{H}$ & $0.250(0.0141)$ & $0.240-0.260$ & \\
\hline & $72 \mathrm{H}$ & $0.635(0.0212)$ & $0.620-0.650$ & \\
\hline & Combined & $0.295(0.2863)$ & $0-0.650$ & \\
\hline \multirow[t]{4}{*}{ 5. Group E } & $24 \mathrm{H}$ & $0.340(0)$ & 0.340 & \\
\hline & $48 \mathrm{H}$ & $0.585(0.0071)$ & $0.580-0.590$ & \\
\hline & $72 \mathrm{H}$ & $0.605(0.0212)$ & $0.590-0.620$ & \\
\hline & Combined & $0.510(0.1324)$ & $0.340-0.620$ & \\
\hline
\end{tabular}

\section{Discussion}

The role of lycopene as an anti-cancer agent for prostatecancerhasbeenwidelyreported[8],[9],[10],[11],[12]. This research used the culture of prostate cancer cell tissues from Indonesian patients that were given different dosages of lycopene with different observation times. The results obtained showed that lycopene had a decreasing effect on caspase- 9 levels at a concentration of $2 \mu \mathrm{M}$ within an observation time of $72 \mathrm{~h}$ and $4 \mu \mathrm{M}$ within an observation time of $48 \mathrm{~h}$ [17]. From the evidence, it seems that with the increase amount of lycopene concentration, the faster the caspase- 9 level decreases. This result is supported by several researchers such as Sapuntzakis and Bowen, who reported that the concentrations $0.1 \mu \mathrm{M}, 0.5 \mu \mathrm{M}, 1 \mu \mathrm{M}$, and $5 \mu \mathrm{M}$ can inhibit the LNCaP (this is not abbreviation, this is a name of cell) prostate cancer cell growth significantly. The cell cycle progress was also repressed by lycopene as proven by Palozza et al. lycopene at the concentration of $2.5 \mu \mathrm{M}-10 \mu \mathrm{M}$ could reduce the DI cyclin that plays a role in the G0/G1 and reduce the reactive oxygen species (ROS) production significantly [18], [19].

An interesting issue in this research was how the decrease of caspase- 9 rate begins with an increase, whether it was given a lycopene concentration of $2 \mu \mathrm{M}$ or $4 \mu \mathrm{M}$, as shown in Table 1. This incidence was not found in previous research. The average increase of the caspase- 9 rate in the beginning of this study was thought to occur as an effect of the antioxidant that causes a high elimination of reactive oxygen species, till it disturbs the homeostatic rate of ROS that leads to cell damage and apoptosis.
High level of ROS might induce cell death and massive cell damage. High ROS level on cancer cell might cause failure in activating P38-MAPK bond which eventually leads to cancer cell death; hence, high ROS levelacted as antiproliferation and apoptosis [20], [21]. This study showed that with prostatic cancer cell death after administration of $2 \mu \mathrm{M}$ lycopene and $48 \mathrm{~h}$ of observation, there caused leakage of caspase- 9 from intracellular to extracellular space, causing caspase- 9 level to increase compared to the control group. This also occurred with the administration of $4 \mu \mathrm{M}$ lycopene.

The mechanism of action of lycopene toward caspase-9 was by inhibiting transduction of DHT signaling which might suppress caspase- 9 expression as elaborated by Liu et al. Dihydrotestosterone would bind with androgen receptor and then form a complex with beta-catenin to modulate the expression of several genes, including caspase-9 gene. Lycopene also increases serine phosphorylation effect on Akt and GSK3 $\beta$, and tyrosine phosphorylation of GSK3, which might prevent cell growth [18]. Kanagaraj et al. stated that the administration of lycopene might induce the production of IGF binding protein-3 (IGFBP-3) which might cause a reduction of caspase- 9 . This caused inhibition of proliferation through MAPK pathway and PI3Akt [22]. This result was also established by Wang, who explained the mechanism of how lycopene might decrease caspase-9 level through inhibition of the insulin receptor phosphorylation process which was stimulated by caspase-9, expression of cyclin D1, and blockage of cell cycle which was stimulated by caspase-9, also increasing insulin growth factor binding protein (IGFBP); should the IGFBP level increase in blood, the protein would bind with caspase-9; thus, caspase-9 was unable to bind with its receptor [23].

This study showed that the administration of lycopene at $1 \mu \mathrm{M}$ concentration had not affected the increase of mean caspase-9 level yet. This result was different with result from Hantz et al. [16], which stated that administration of physiologic concentration $(0.3 \mu \mathrm{M}$ and $1 \mu \mathrm{M}$ ) of lycopene might reduce the transmembrane potential of LNCaP cancer cell mitochondria, causing release of cytochrome $\mathrm{C}$ and eventually induce significant apoptosis [19]. Similar to Hantz et al., Sapuntzakis and Bowen reported the same results [24].

The average increase in caspase- 9 level was observed during the administration of $2 \mu \mathrm{M}$ and $4 \mu \mathrm{M}$ lycopene on each observation time. With $2 \mu \mathrm{M}$ lycopene, the increase of caspase- 9 occurred after $48 \mathrm{~h}$; meanwhile, with $4 \mu \mathrm{M}$ lycopene, the increase had already been observed during the first 24 to $48 \mathrm{~h}$ and $72 \mathrm{~h}$ of observation time. Similar result was also reported by Teodoro et al. that lycopene with a concentration of $5 \mu \mathrm{M}$ might reduce LNCaP, DU145, and PC3 cancer cell viability within $72 \mathrm{~h}$ and this result is parallel with the increase in lycopene concentration $(10 \mu \mathrm{M}$ and $20 \mu \mathrm{M})$ [25]. Ford et al. reported that DU145 cancer cell proliferation could be inhibited with lycopene at 
$15 \mu \mathrm{M}$ and $25 \mu \mathrm{M}$ (supraphysiologic concentration) up to $10 \%$ and $19 \%$ respectively within $72 \mathrm{~h}$; meanwhile, $92-93 \%$ apoptosis occurred on the concentration of $1 \mu \mathrm{M}, 15 \mu \mathrm{M}$, and $25 \mu \mathrm{M}$ within $72 \mathrm{~h}$ [26]. Teodoro et al. also reported that there was an increase in apoptosis of DU145 cancer cells after incubated with $3 \mu \mathrm{M}$ lycopene for $96 \mathrm{~h}$ [25].

Lycopene with $2.5 \mu \mathrm{M}, 5 \mu \mathrm{M}$, and $10 \mu \mathrm{M}$ concentration might reduce AKT phosphorylation on prostatic $\mathrm{LNCaP}$ cancer cells. AKT was antiapoptosis, thus, reduction in AKT might increase Bax and Bak activation for apoptosis to happen. This result was explained using a study by Palozza et al. which stated that lycopene reduced expression of $\mathrm{Bcl}-2$ and $\mathrm{Bcl}-\mathrm{xl}$ significantly, both of which were known as antiapoptotic protein, and increase Bax which was a proapoptotic protein [27].

The limitation of this study was that observation time was limited to only up to $72 \mathrm{~h}$; thus, it was assumed that the reduction of caspase-9 level has not yet reached the maximum level. Another limitation was that the proliferation of prostatic cancer cells through subculture did not achieve an appropriate number of cells to conduct repeated measurement for more than twice. Moreover, prostatic cancer tissues, which fulfilled inclusion criteria, were scarce; and calculation of the number of prostatic cancer cells (colony) based on concentration and observation time was not conducted after lycopene administration.

\section{Conclusion}

It could be concluded from this study that there was significant increase of caspase- 9 levels on Indonesian human prostatic cancer cells by administration of various concentrations of lycopene and observation time. Lycopene could be administered as an adjuvant for advanced Gleason 6 stage prostatic cancer patients to increase apoptosis and eventually inhibit the progressivity of cancer cells.

\section{References}

1. Crawford E. Epidemiology of prostate cancer. Urology. 2003;62(6):3-12. https://doi.org/10.1016/j.urology.2003.10.013 PMid: 14706503

2. Sim HG, Cheng CW. Changing demography of prostate cancer in Asia. Eur J Cancer. 2005;41(6):834-45. https://doi. org/10.1016/j.ejca.2004.12.033 PMid:15808953

3. Antonarakis ES, Carducci MA, Eisenberger MA. Treatment of castration resistant prostate cancer. In: Campbell Walsh Urology $10^{\text {th }}$ ed., Vol. 110. Philadephia, PA: Saunders Elsevier; 2012. p. 2954-70.

4. Umbas R, Tambunan N. Peran faktor nutrisi pada pencegahan kanker prostat. Indones J Cancer. 2014;8(3):135-40.

5. Vecchia CL. Mediterranean epidemiological evidence on tomatoes and the prevention of digestive-tract cancers Proc Soc Exp Biol Med. 1998;218(2):125-8. https://doi. org/10.3181/00379727-218-44276

PMid:9605210

6. Rao AV. Agarwal S. Review, role of antioxidant lycopene in cancer and heart disease. J Am Coll Nutr. 2000;19(5):563-9. https://doi.org/10.1080/07315724.2000.10718953 PMid:11022869

7. Basu A, Imrhan V. Tomatoes versus lycopene in oxidative stress and carcinogenesis: Conclusions from clinical trials. Eur J Clin Nutr. 2007;61(3):295-303. https://doi.org/10.1038/ sj.ejcn. 1602510

PMid:16929242

8. Giovannucci E. A review of epidemiologic studies of tomatoes, lycopene, and prostate cancer. Exp Biol Med (Maywood). 2002;227(10):852-9. https://doi. org/10.1177/153537020222701003

PMid: 12424325

9. Mills PK, Beeson WL, Phillips RL, Fraser GE. Cohort study of diet, lifestyle, and prostate cancer in adventist men. Cancer. 1989;64(3):598-604. https://doi.org/10.1002/10970142(19890801)64:3<598::aid-cncr2820640306>3.0.co;2-6 PMid:2743254

10. Hadley CW, Miller EC, Schwartz SJ, Clinton SK. Tomatoes, lycopene, and prostate cancer: Progress and promise. Exp Biol Med (Maywood). 2002;227(10):869-80. https://doi. org/10.1177/153537020222701006 PMid: 12424328

11. Etminan M, Takkouche B, Caamano-Isorna F. The role of tomato products and lycopene in the prevention of prostate cancer: A meta-analysis of observasional studies. Cancer Epidemiol Biomarkers Prev. 2004;13(3):340-5 PMid:15006906

12. Siler U, Herzog A, Spitzer $V$, Seifert $N$, Denelavas $A$ Hunziker PB, et al. Lycopene effects on rat normal prostate and prostate tumor tissue. J Nutr. 2005;135(8):2050S-2. https://doi. org/10.1093/jn/135.8.2050s PMid: 16046739

13. Tang $L$, Jin $T$, Zeng $X$, Wang JS. Lycopene inhibits the growth of human androgen-independent prostate cancer cells in vitro and in balb/c nude mice. J Nutr. 2005;135(2):287-90. https://doi. org/10.1093/jn/135.2.287

PMid: 15671228

14. Obermuller-Jevic UC, Olano-Martin E, Corbacho AM, Eiserich JP, van $\operatorname{der}$ Vliet A, Valacchi $G$, et al. Lycopene inhibits the growth of normal human prostate epithelial cells in vitro. J Nutr. 2003;133(11):3356-60. https://doi.org/10.1093/jn/133.11.3356 PMid:14608044

15. Van Breemen RB, Pajkovic N. Multitargeted therapy of cancer by lycopene. Cancer Lett. 2008;269(2):339-51. https://doi. org/10.1016/j.canlet.2008.05.016 PMid: 18585855

16. Khan N, Adhami VM, Mukhtar H. Apoptosis by dietary agents for prevention and treatment of cancer. Biochem Pharmacol. 2008;76(11):1333-9. https://doi.org/10.1016/j.bcp.2008.07.015 PMid:18692026

17. Freshney RI. Culture of Animal Cell: A Manual of Basic Technique in Primary Culture. $5^{\text {th }}$ ed. New Jersey: John Wiley and Sons; 2005. p. 175-97. 
18. Liu X, Allen JD, Arnold JT, Blackman MR. Lycopene inhibits IGF-I signal transduction and growth in normal prostate epithelial cells by decreasing DHT-modulated IGF-I production in co-cultured reactive stromal cells. Carcinogenesis. 2008;29(4):816-23. https://doi.org/10.1093/carcin/bgn011

PMid:18283040

19. Hantz HL, Young LF, Martin KR. Physiologically attainable concentrations of lycopene induce mitochondrial apoptosis in Incap human prostate cancer cells. Exp Biol Med (Maywood). 2005;230(3):171-9. https://doi. org/10.1177/153537020523000303

PMid:15734720

20. Gorrini C, Harris IS, Mak TW. Modulation of oxidative stress as an anticancer strategy. Nat Rev Drug Discov. 2013;12(12):931-47. https://doi.org/10.1038/nrd4002 PMid:24287781

21. Glasauer A, Chandel NS. Targeting antioxidants for cancer therapy. Biochem Pharmacol. 2014;92(1):90-101. https://doi. org/10.1016/j.bcp.2014.07.017

PMid:25078786

22. Kanagaraj P, Vijayababu MR, Ravisankar B, Anbalagan J, Aruldhas MM, Arunakaran J. Effect of lycopene on insulinlike growth factor-I, IGF binding protein-3 and IGF Type-I receptor in prostate cancer cells. J Cancer Res Clin Oncol. 2007;133(6):351-9. https://doi.org/10.1007/s00432-006-0177-6 PMid:17219202
23. Wang XD. Lycopene metabolism and its biological significance. Am J Clin Nutr. 2012;96(5):1214S-22. https://doi.org/10.3945/ ajcn.111.032359

PMid:23053559

24. Sapuntzakis MS, Bowen PE. Role of lycopene and tomato products in prostate health. Biochim Biophy Acta. 2005;1740(2):202-5. https://doi.org/10.1016/j. bbadis.2005.02.004

PMid:15949687

25. Teodoro AJ, Oliveira FL, Martins NB, Maia GA, Martucci RB, Borojevic R. Effect on lycopene on cell viability and cell cycle progression in human cancer cell line. Cancer Cell Int. 2012;12(1):36. https://doi.org/10.1186/1475-2867-12-36 PMid:22866768

26. Ford NA, Elsen AC, Zuniga K, Lindhield BL, Erdman JW. Lycopene and apo-12'-lycopenal reduce cell proliferation and alter cell cycle progression in human prostate cancer cells. Nutr Cancer. 2011;63(2):256-63. https://doi.org/10.1080/01635581.2 011.523494

PMid:21207319

27. Palozza P, Colangelo M, Simone R, Catalano A, Boninsegna A, Lanza $\mathrm{P}$, et al. Lycopene induces cell growth inhibition by altering mevalonate pathway and ras signalling in cancer cell lines. Carcinogenesis. 2010;31(10):1813-21. https://doi.org/10.1093/ carcin/bgq157

PMid:20699249 